O. Terentiev, Dr. Sciences., Prof. ORCID 0000-0003-2523-2804

N. Sergienko, Assos. Prof. ORCID 0000-0001-8284-9072

A. Huzan, student

National Technical University of Ukraine «Igor Sikorsky Kyiv Polytechnic Institute»

\title{
USE OF INNOVATIVE SYSTEMS FOR EFFICIENT DRILLING OF WELLS IN THE QUARRY OF UKRAINE
}

\begin{abstract}
Almost all over Ukraine in the bowels of the Ukrainian crystal shield is more than 500 million $\mathrm{m}^{3}$ of explored reserves of high quality natural building and finishing stone. Of particular interest are granite deposits as the main strategic raw material for the construction of industrial, defense and civil structures, roads, runways, airfields, transport tunnels, subways and more. Today, more than 150 quarries in Ukraine extract valuable raw materials for the country - natural stone. At the same time, given the high strength and abrasiveness of granites, their extraction is extremely complex, expensive, time consuming. There are no machines that could directly extract strong granite rocks of volcanic and metamorphic origin. To ensure the required volumes of granite mining, it is necessary to pregrind the monolith of the rock, which is carried out by drilling and blasting. These complex technological operations provide powerful drilling rigs that perform drilling work in strong and very strong rocks [1].

In the presented researches the basic indicators influencing efficiency of drilling rigs on quarries of Ukraine are analyzed and established. Rational methods of rock destruction for specific geological conditions of a mining enterprise are considered, substantiated and recommended. Optimization of drilling efficiency and productivity was performed by choosing the method of destruction, hardness of rocks, type of drilling machine and parameters of tools for destruction of rocks [2]. The calculation method presented in the work allows to limit the amount of dust pollution depending on the speed, depth of drilling, distance from the well for blasting, which will control the optimal modes of operation of the drilling machine and drilling modes. The obtained research results confirmed the correctness and efficiency of new innovative systems for drilling hard rocks in the quarries of Ukraine.
\end{abstract}

Keywords: quarry, destruction of rocks, drilling rig, pneumatic striker.

Introduction. One of the key processes in the quarries is drilling work. Effectiveness of their implementation depends primarily on the performance of the drilling equipment. Drilling machines must provide high performance, low cost, environmental requirements required diameter and depth of drilling have independent individual drive, high mobility and speed.

Analysis of the problem. Improving the efficiency of drilling and blasting operations in the quarries of Ukraine is the main direction that ensures a constant increase in the extraction of natural resources. Today, open pit mines use a wide range of drilling rigs and technologies to drill wells with diameters ranging from 40 to $350 \mathrm{~mm}$ in hard and very hard formations. The main technical and economic indicators of enterprises depend on the efficiency and productivity of drilling. The drilling process is also characterized by significant release of drill dust and explosion products, which have a large impact on environmental pollution and the health of workers.

The extremely high cost and low efficiency of drilling operations is a consequence of the use of outdated drilling rigs with low productivity and ineffective mining destructive tools in the Ukrainian open pits. The development of the latest explosive materials with high energy of destruction allows, during blasting operations, to reduce the diameter of drilled holes to $100-150 \mathrm{~mm}$. At the same time, these purposes require more productive, powerful and reliable drilling equipment, which provides high-speed drilling in hard rocks. In recent years, the productivity of drilling rigs has stabilized, but the mining and geological conditions of production have deteriorated significantly. The discrepancy between the parameters and modes of drilling leads to a constant increase in the costs of drilling in hard rocks, which reach $30-40 \%$ of the total cost of mining operations [3]. In the modern ecological aspect of protecting nature from mining, it is also important to control the release of large amounts of fine dust during drilling, which affects the health of personnel and environmental pollution.

Therefore, the selection and implementation of productive drilling equipment with substantiation of the main parameters of well drilling to ensure high technical and economic indicators of mining, environmental protection and workers' health is an important theoretical and practical task of the mining industry.

The article is aimed at research and comparative assessment of the main technological and technical parameters of existing and newest innovative drilling equipment for a wide range of complex geological conditions in the quarries of Ukraine.

The main material. Table 1 shows the main characteristics of the operating drilling rigs SBS-250, SBU-125, Atlas Copco in the quarries of Ukraine. The main SBS drilling rigs are designed for drilling vertical wells with a diameter of $\mathrm{dc}=160-350 \mathrm{~mm}$ and a depth of up to $35 \mathrm{~m}$. The use of these machines with roller cone bits for crushing

(C) O.M. Терентьєв, М.I. Сергієнко, А.І. Гузан, 2020 
rocks with a strength factor $f=6-18$ has low drilling speeds due to their technical imperfections. For example, the use of wells with a diameter of more than $200 \mathrm{~mm}$ in hard formations does not lead to a decrease in unit costs. In rocks with high resistance to fracture, the best performance is achieved when using wells with a diameter of 100$180 \mathrm{~mm}$. The use of wells with a diameter of 215-250 mm under these conditions leads to an increase in explosive costs by $20-40 \%$ [4]. The main disadvantages of SBC machines are large mass and low resistance of bits in heavily drilled formations, high noise, vibration and dust emissions, accidents, maintenance complexity, low speed [5]. The development of new highly efficient drilling equipment has allowed to improve drilling equipment for drilling with diameters from 100 to $180 \mathrm{~mm}$, which significantly increases productivity and reduces energy consumption of the process. All existing theories of mechanical destruction of rocks can be reduced to the energy theory, according to which the preferred method of destruction, modes and duration of the process, providing the minimum energy consumption for drilling [6].

Table 1. Technical specifications and parameters of drilling rigst

\begin{tabular}{|l|c|c|c|}
\hline \multirow{2}{*}{\multicolumn{1}{|c|}{ Indicators }} & \multicolumn{2}{c|}{ Drilling rigst } \\
\cline { 2 - 4 } & SBC -250 & SBU-125 & $\begin{array}{c}\text { ROC L8 } \\
\text { "Atlas Copco", }\end{array}$ \\
\hline Productivity, m / h & 15 & 10 & $16-45$ \\
\hline The range of strength of rocks, f & $12-18$ & $10-14$ & 317 \\
\hline Installed power, kW & 398 & 80 & $0-90^{\circ}$ \\
\hline Range drilling (H. / Vert.), Deg & $0-30^{\circ}$ & $0-30^{\circ}$ & 3.4 \\
\hline Driving speed km / h & $0.78-1.2$ & 1.0 & 54 \\
\hline Maximum drilling depth, m & 32 & 25 & 16.8 \\
\hline Hole diameter's, mm & $250-270$ & $125-160$ & 203 \\
\hline Weight, $\mathrm{T}$ & 75.0 & 8.0 & Down-the-hole Copco- \\
\hline Drilling method, type & cutting drill & DTH P-125 & $44 / 64$ \\
\hline Efforts filing, kN & 300 & 20 & 40 \\
\hline
\end{tabular}

The principle drilling cutting method is based on the actions of large axial forces and torque on the drill [7]. Summed to slaughter borehole through the drill rod Nash power (W), which determines the performance of the method is calculated by the formula:

$$
N_{ø}=3 \cdot m_{0} \cdot D \cdot n \cdot G, \mathrm{~m}
$$

where $\mathrm{m}_{0}$ - coefficient taking into account the type of bit and contact strength of rocks; D - diameter bits, $\mathrm{m} ; \mathrm{n}$ number of revolutions bit; $\mathrm{G}$ - axial force on a bit, $\mathrm{N}$.

When percussion-drilling method, using submersible pneumatic drummer. Desktop Authority operates cyclic shock loading at low effort delivery and torque. Summed with the capacity to slaughter NY (Wt) is defined by the formula:

$$
N_{\dot{o}}=\frac{0,45 \cdot \pi \cdot R^{2} \cdot P_{c} \cdot V_{\dot{o}}}{2 \cdot(1+\tau)},
$$

where R - striker radius, m; Pc - the average pressure in the chamber of the forward striker, Pa; - first speed, $\mathrm{m} / \mathrm{s}$; - the ratio of the forward air-strike time to time reverse (=1.4 - 1.6); A - energy single blow, J; - impact rate, Hz.

From formula (1) and (2) it follows that during drilling of one diameter drilling opportunities to increase productivity and increasing pressure determined first speed. This required axial force $G(H)$ on the shock machine is determined by the expression:

$$
G=\frac{2 \cdot A \cdot v}{V_{y} \cdot \eta}
$$

where $\eta=0.5-0.7$ - efficiency

The principles of the axial force during cutting and air percussion different. When cutting drilling axial force is crucial for power on bottom hole. When air percussion axial clamping force pneumatic drummer to face no 
significant effect on the efficiency of the destruction of rocks. In connection with this problem drilling wells submersible shock machines removed. There is a very important indicator of the removal power $\mathrm{W}(\mathrm{Wt})$ per unit axial force:

For the cutting method, we have:

$$
\mathrm{W}=\mathrm{N} / \mathrm{G} \text {, }
$$

$$
W_{\varnothing}=\frac{N_{\varnothing}}{G}=3 \cdot m_{0} \cdot D \cdot n,
$$

and for air percussion:

$$
W_{\dot{o}}=\frac{N_{\dot{o}}}{G}=0,5 \cdot V_{\dot{o}} \cdot \eta,
$$

Having real data in drilling wells with a diameter $\mathrm{D}=0,215 ; \mathrm{m}_{0}=0,042 ; \mathrm{D}=0,215 ; \mathrm{n}_{\mathrm{B}}=1,33 \mathrm{c}^{-1} ; \mathrm{V}_{\mathrm{y}}=8 \mathrm{~m} / \mathrm{s} ; \eta=$ 0.5 . get $=\mathrm{W}_{\omega}=0.036 \mathrm{Wt} / \mathrm{N}$ and $\mathrm{Wy}=2 \mathrm{Wt} / \mathrm{N}$.

It follows that the power that is removed from the unit axial force when cutting drilling of 40-50 times less than the percussion-way. This is one of the most important arguments advantages air percussion drilling method, especially for wells

Use tools with an impact-rotary method of drilling with submersible pnevmoudarnykamy is one of the most promising and effective ways. With this method, the destruction of rocks made by impact shock loads at low axial pressures and speeds, and therefore such machines have a much higher performance and minimum energy drilling process [8]. Recently, drilling rigs of the Swedish engineering concern Atlas Copco, equipped with a pneumatic for down-the-hole hammer for rotary drilling, have been operated in the quarries of Ukraine. These rigs can drill holes with a diameter of 85 to $305 \mathrm{~mm}$. with a drilling depth of up to $54 \mathrm{~m}$, in rocks of medium and high strength. They are equipped with replaceable drill rods 5-7 m long with automatic installation during operation. The design of the base machine and drilling rigs allows drilling wells with angles of 0-90 degrees (Figure 1). They have high productivity and speed of drilling, mobility and speed, processing performance, low environmental impact, safe in operation [9].

a)

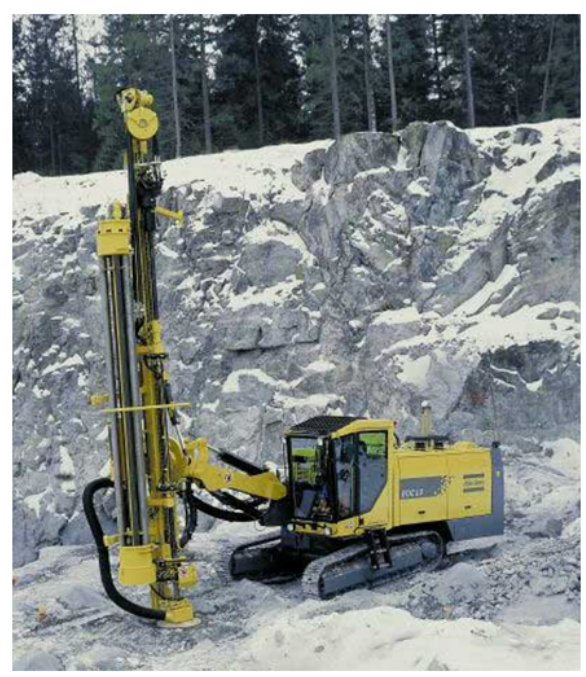

b)

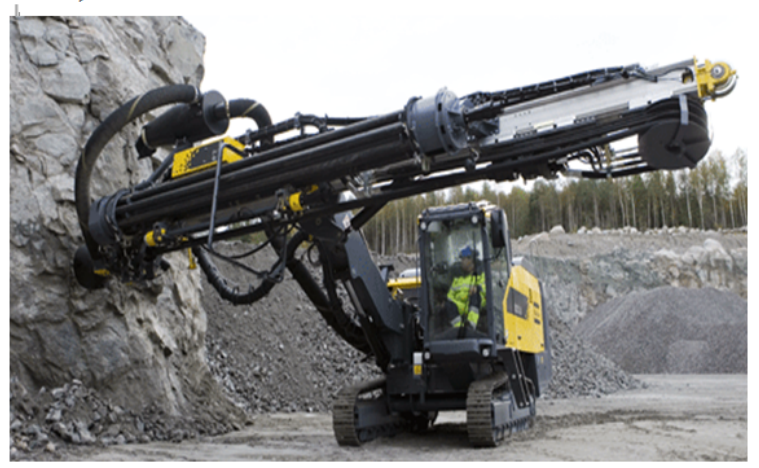

Figure 1. Drilling machine "Atlas Copco" for drilling wells career: a) - vertical; b) - horizontal.

Working equipment machine including compressor, mounted on a single platform. Having tracked and small size provide sufficient conditions for limited mobility and maneuverability. Equipment of diesel driven machine allows it to operate autonomously in small venues and working in an environment where there is no electricity supply system [10]. High-performance drilling rigs with pneumatic punches as provided by the drilling speed (the speed of penetration into the rock) and by minimizing the auxiliary and preparatory operations. Drilling machines "Atlas Copco" equipped with automatic extension rods, thanks to what the ratio of net drilling time to time for preparatory operations is 70/30. Efficiency drilling stalls "Atlas Copco provides powerful submersible pneumatic drummer or hydraulic hammer, designs and sizes which can drill holes with a diameter dc from 85 to $305 \mathrm{~mm}$ in rocks of medium strength to super-strong (Table 2). The same drilling machine may use several sizes of pneumatic drummer COP. 
ISSN 1813-5420 (Print). Енергетика: економіка, технології, екологія. 2020. № 2

Table 2. Specifications pneumatic submersible rock breaking hammer "Atlas Copco"

\begin{tabular}{|c|c|c|c|c|c|}
\hline \multirow{2}{*}{ Parameters pneumatic drummer COP } & \multicolumn{5}{|c|}{ Rock drill down-the-hole (DTH) COP } \\
\cline { 2 - 5 } & COP-34 & COP-44 & COP-54 & COP-64 & COP-84 \\
\hline Leight, MM & 982 & 1059 & 1143 & 1312 & 1458 \\
\hline Hole diametr's, MM & 84 & 100 & 125,5 & 142 & 160 \\
\hline Weight, Kg & 32 & 49 & 84 & 124 & 155 \\
\hline Working pressure, bar & $6-25$ & $6-25$ & $6-25$ & $6-25$ & $6-25$ \\
\hline Air consumption, 1/s at: & & & & & \\
10 bar & 82 & 105 & 126 & 175 & 176 \\
18 bar & 165 & 185 & 245 & 342 & 345 \\
24 bar & 215 & 250 & 370 & 475 & 480 \\
\hline Drill still, MM & $85-105$ & $105-140$ & $127-152$ & $165-203$ & $195-305$ \\
\hline
\end{tabular}

The overall look and design submersible pneumatic drummer COP which is equipped with a drilling machine "Atlas Sopco" shown in Figure 2.

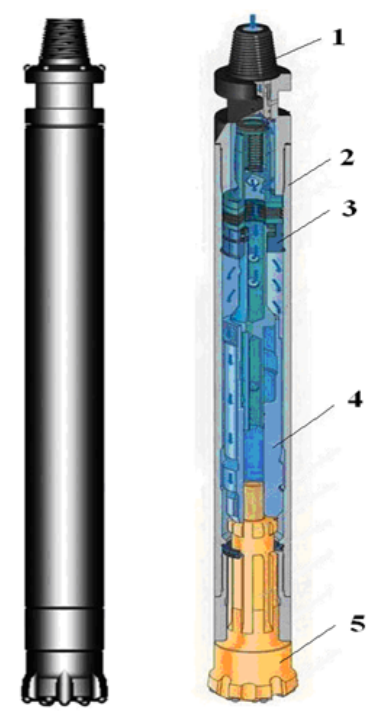

Figure 2 - General view and design of the drilling rig "Atlas Copco".

1 - connecting node with a drill; 2 - the body of the drummer; 3 - spool distribution mechanism; 4 - shock piston; 5 - rock-destroying tool.

Atlas Copko submersible rock drills use special heavy duty drill bits for crushing hard and abrasive formations (fig. 3). They are equipped with ultra-hard, high-strength tungsten carbide and cobalt carbide spherical inserts for productive rock crushing and minimal displacement during high speed drilling [10,11].

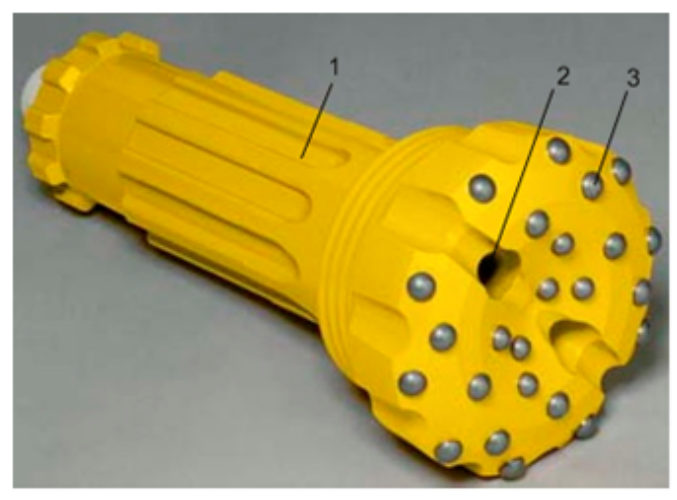

Figure 3. Crown of "Atlas COPCO" machine for crushing extra hard rocks.

1 - tool attachment point; 2 - ventilation holes for rock removal; spherical carbide insert. 
To avoid excessive crushing of the rock in the well and the risk of jamming, waste is removed from the well at regular intervals (3-5 seconds) by blowing air in accordance with one of the three operating modes of the Copco air hammer (Fig. 4).

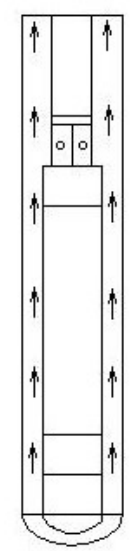

a

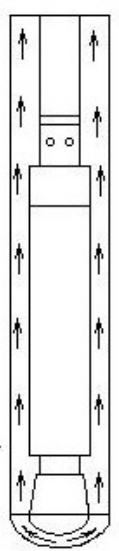

B

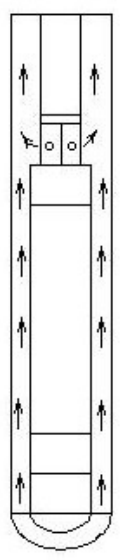

c

Figure 4 - Scheme of blowdown and cuttings removal: $a$ - blowdown from the bottom of the well; $b$ blowing with a percussion mechanism; $\mathrm{c}$ - purging by actuation of the purge valve. Scheme of blowing and sludge removal: a - blowdown from the bottom of the well; $b$ - blowdown of the percussion mechanism; $\mathrm{c}$ - actuation of the blowdown valve.

When blowing the well according to the scheme (a, Fig. 4), the percussion mechanism of the pneumatic hammer stops as soon as the striker rises and falls together with the bit, therefore a large volume of air is blown through the striker and is well cleaned. According to the scheme (b, Fig. 5), the percussion mechanism is triggered and the striker is lowered to the bottom of the well, setting the bit to the percussion position and using a special purge valve (c, Fig. 4).

The use of an original well blowdown scheme and a vacuum cleaner above the wellhead allowed solving a very important task - to reduce emissions and dust concentration, as well as to reduce the man-made load on the environment and workers' health. Dust emissions Q from the drilling rig at a certain distance from the drilling site $\mathrm{S}$ for different types of machines (Fig.5).

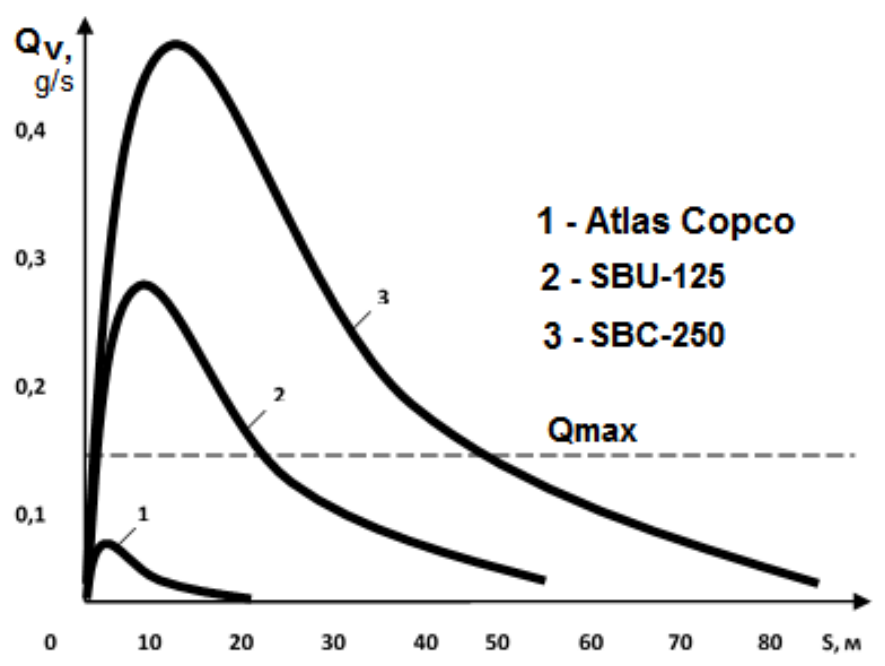

Figure 5 - Dependence of dust emissions on the type of drilling rig

The proposed method for determining dust emissions when drilling blast holes with drilling rigs and methods for destroying rocks made it possible to determine the amount of dust released into the environment. Mass of dust released when drilling wells:

$$
\mathrm{m}_{n \sigma}=\sum_{i=1}^{n} Q_{o p i} \cdot q_{i} \cdot T_{i} \cdot K_{2} \cdot 10^{-3},
$$


where: Qopi is the volumetric power of the $\mathrm{i}$-th drilling machine; dust extraction of dust from $1 \mathrm{~m} 3$ of drilled rock of the i-th car, $\mathrm{kg} / \mathrm{m} 3$; Net operating time of the drilling machine per year, $\mathrm{h} /$ year; $\mathrm{n}$ - the total number of working machines in the quarry; $\mathrm{K} 2$ - coefficient that takes into account the humidity of the material.

The value of $Q_{o p i}$ can be obtained from the indicators of technical capacity:

$$
Q_{\text {опі }}=Q_{\text {лп }} \frac{\pi d^{2}}{4} \cong 0,785 Q_{\text {лп }} \cdot d^{2}, m^{3} / \mathrm{h}
$$

Mass of dust released when drilling wells per unit time:

$$
m_{\text {бпр }}=Q_{\text {опі }} \cdot q_{\mathrm{i}} / 3600, \mathrm{~g} / \mathrm{s}
$$

The maximum one-time emissions of hazardous products from drilling are shown in the table. 4 :

Table 4 - Results of calculating dust emissions during the operation of various drilling rigs

The results of the research carried out on the productivity of drilling rigs in the quarries of Ukraine are presented in the graphs (Fig. 6). The dependences of the drilling speed $\mathrm{V}_{\mathrm{b}}$ on the strength of rocks in the range $\mathrm{f}=5-20$ have been established. The research was carried out for quarries of Ukraine, where rocks and other minerals such as granite, marble, gabbro, labradorite, iron quartzite, diabase, diorite, travertine, sandstones, shales are developed and mined in difficult conditions.

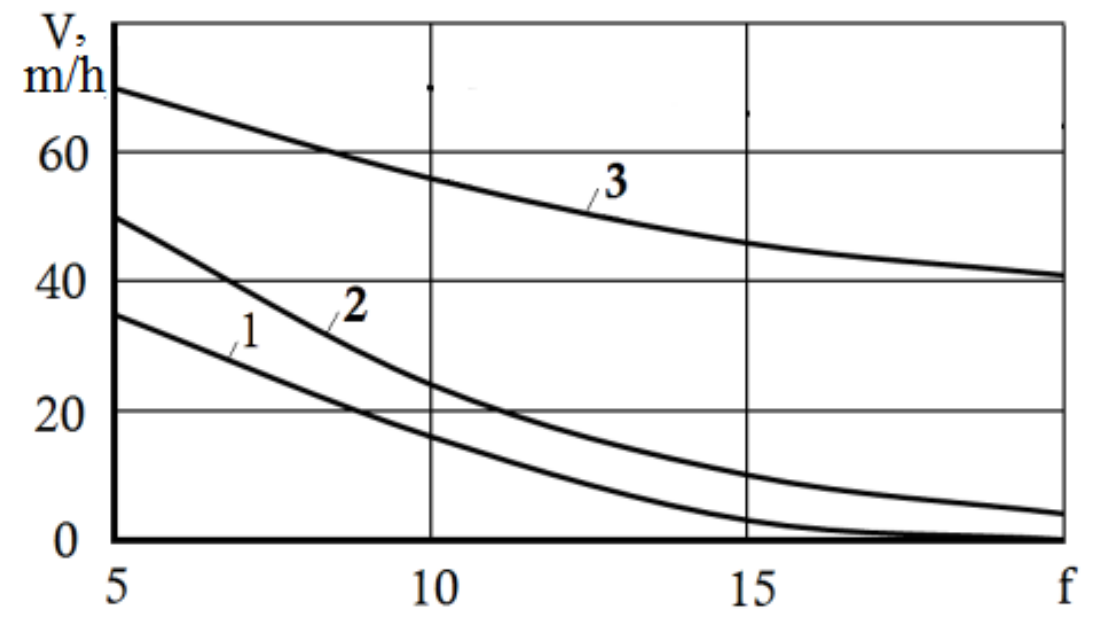

Figure 6. Dependence of the mechanical drilling speed on the strength of rock.: 1 - SBC- 250; 2 - SBU- 125; 3 - "Atlas Copco ROC-L8".

As can be seen from the graph (Fig. 6), with rock strength $\mathrm{f}=10$, the drilling speed of the ROC-L8 drilling rig with COP DTH hammers is 2 times higher than that of SBU-125, and 6 times higher then SBC-250. When drilling wells with rock strength $\mathrm{f}=14$, the productivity of the ROC-L8 drilling rig is 3 times higher than that of the SBU125 , and 4 times higher than that of the SBC-250. With rock strength $\mathrm{f}=18$, the ROC-L8 rig has a 2 -fold advantage in drilling speed over SBU-125, and 6 times over SBC-250. The productivity of ROC-L8 drilling rigs in the quarries of Ukraine in 2018 was $5600 \mathrm{~m}$, which is $20 \%$ higher than that of the SBU-125 (4650 m). The productivity of the SBC-250 machine was $4200 \mathrm{~m}$ per month. Figure 7 shows the structure of discounted costs for drilling one running

\begin{tabular}{|c|c|c|c|c|c|c|c|}
\hline \multirow[t]{2}{*}{$\begin{array}{c}\text { Types } \\
\text { drilling rigs }\end{array}$} & \multicolumn{5}{|c|}{$\begin{array}{l}\text { Average volume productivity, Qopi } \mathrm{m}^{3} / \mathrm{h} \text {, by } \\
\text { rock hardness }\end{array}$} & \multirow[t]{2}{*}{$\begin{array}{c}\text { Dust } \\
\text { suppressors }\end{array}$} & \multirow[t]{2}{*}{$\begin{array}{l}\text { Specific dust release, } \\
\mathrm{kg} / \mathrm{m}^{3}\end{array}$} \\
\hline & $f=5-10$ & $f=10-14$ & $f=12-14$ & $f=14-16$ & $f=16-18$ & & \\
\hline \multirow[t]{3}{*}{ SBC } & \multirow{3}{*}{1,46} & \multirow{3}{*}{1,41} & \multirow{3}{*}{1,21} & \multirow{3}{*}{0,98} & \multirow{3}{*}{0,83} & ВПП & 0,9 \\
\hline & & & & & & УСП & 1,3 \\
\hline & & & & & & БЗП & 3,2 \\
\hline \multirow[t]{3}{*}{ SBU } & \multirow{3}{*}{2,18} & \multirow{3}{*}{2,02} & \multirow{3}{*}{1,80} & \multirow{3}{*}{1,50} & \multirow{3}{*}{1,29} & ВПП & 0,7 \\
\hline & & & & & & УСП & 0,9 \\
\hline & & & & & & БЗП & 2,35 \\
\hline Atlas Copco & 6,07 & 5,61 & 5,161 & 4,65 & 4,29 & ВПП & 0,3 \\
\hline
\end{tabular}
meter of a well for various drilling rigs. 

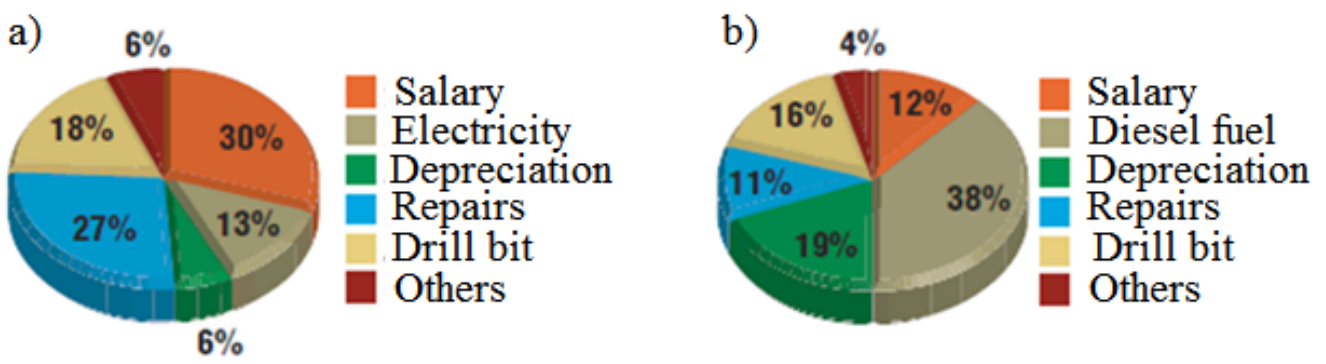

Figure 7. Structure of the cost of drilling: a) - SBC; b) - Atlas Copco.

Cost structure analysis shows that Atlas Copco's pneumatic submersible drilling rigs COP outperforms the SBC roller cutters primarily in terms of annual productivity [12]. This is due to the destruction of hard rocks with high-performance pneumatic hammers, an autonomous diesel drive, full automation of drilling support (replacement and extension of drill rods, replacement of bits, horizontal drilling), which reduces the drilling time and shortens the drilling time. transition from well to well. All Atlas Copco mechanisms are hydraulically driven, which provides good control and optimization of drilling parameters. But it should be borne in mind that while foreign cars are new, the cost of their repair is insignificant, but every year of operation it will grow.

Inefficient drilling rigs SBC-250 and SBU-125 are limited by their technical capabilities and energy efficiency, as well as by the conditions of use. Proceeding from the fact that drilling speed is an integral and comprehensive indicator of drilling operations in open pits, and especially the destruction of hard and heavy rocks, the use of Atlas Copco drilling machines with COP DTH hammers is the best option and a very promising direction of drilling equipment. The use of high-performance Atlas Copco machines, along with the development and implementation of modern explosives, makes it possible to reduce the drilling diameter, which will lead to a decrease in blasting operations, which significantly improves both the explosive and technical and economic indicators of mining enterprises in general.

Conclusions. It is necessary to select drilling equipment on the basis of a technical and economic calculation of the conditions for achieving the minimum cost of the entire complex of processes: drilling, explosives, excavation, transportation, crushing, as well as the cost of explosives. The results of operation of Atlas Copco machines with COP DTH hammers have confirmed their effectiveness in drilling in a wide range of strengths in open pit mining [13].

COP down-the-hole hammers are more promising in use than SBC drilling rigs due to their increased productivity, efficiency, and drive motor power. High mobility and speed reduce technical waste of time. Atlas Copco drilling rigs provide high technical capabilities for high-precision drilling of wells with a diameter of 35 to $305 \mathrm{~mm}$, a depth of $54 \mathrm{~m}$ in the range of $0-90$ degrees.

The well blowdown system leads to high purity of cuttings, which qualitatively affects the efficiency of blasting operations. A reliable dust extraction system and a sealed cabin ensure the necessary hygienic standards during drilling, minimize vibration and noise impact on personnel and the environment. Reduces the emission of drill dust into the environment. The disadvantage is the high initial cost of drilling rigs and high requirements for the quality of the working fluid of the hydraulic drive.

Analysis of studies of the efficiency of Atlas Copco drilling machines in foreign and Ukrainian open pits shows their high productivity, efficiency and promising application.

\section{REFERENCES}

1. V.F. Byzov, "Osnovy technolohii girnychogo vyrobnyctva”, pidruchnyk, "Girnyctvo", Kryvyj Rig,: Mineral, p. 247, 2000.

2. Z.R. Malanchuk, V.S. Havrish and V.A. Striha, "Technolohii vidkrytoi rozrobky korysnyh kopalyn”, navch. posib., Rivne, NUVGP, p. 285, 2013.

3. O.M. Terentiev, A.J. Klechov, A.I. Kruchkov and N.I. Sergienko, "Technologichni parametry rujnuvannja girskyh porid pry clasychnomu i molekuljarno-hvyljovomu pidhodah", Energetyka: ekonomika,technologii, ekologiya: Scientific Journal, no.1, pp. 73-82, 2019.

4. Yu.I. Protasov, "Razrushenie gornyh porod", Uchebnik,Izdatelstvo: Gornaya kniga, ISBN: 5-7418-00327; p.455. 2003.

5. V.V. Olizarenko, "Osnovy ekspluatacii gornyh machine i oborudovaniya", ucheb.posobie, M.: Nedra, p.395, 2008.

6. O.M. Terentiev, A.J. Klechov and N.I. Sergienko, " Statyko-dynamichne rychlennja merzlyh porid”, Naukoviy Journal “Geoinzhenerija”, vol.1, pp. 28-39, 2020. 
7. B.A. Katanov, "Perspektivy razvitiya burovogo oborudovaniya karierov", Fundamentalnye issledovaniya, no.12-2, pp. 228-230, 2007.

8. R.Yu. Poderny. Stanki rotary drilling wells on open tender career, Hornaja elektromehanyka, no. 12, pp. $25-27,2006$.

9. B.A. Katanov, M.s. Safonov, "Instrument dlja burenija vzryvnyh skvazhin na karjerah". Moskwa: Nedra, p.173, 2014.

10. N.N. Strabykin, “Technika bureniya vzryvnych skvazhin v merzlyh porodah”, M.; Nedra, p.172,1989.

11. M.I. Sergienko, V.P. Kotljarov, "Perspektyvni metody pidvychennya robotozdatnosti detaley girnychyh mashyn lazernoyu obrobrkoyu“, Girnyctvo, Zbirnyk naukovyh prac,.-К: НТУУ “КПІ” ЗАТ “Техновибух”, 2011.Вип. 15 Р. 108-115

12. A.S.Tanayno, A.A.Lipin, "Sostojanie i perspektivy udarno-vrachatelnogo burenija vzryvnyh skvazhin na karjerah", Physico-tehnycheskye problemyrazrabotki poleznyh iscopaemyh.Ucheb.posob. M.:Nedra, p.182, 2004.

13. http://www.atlas.copco. Burovi stanky "Atlas Copco" dlya vidkrytysh hirnychyh robit. Sayt kompanii "Atlas Copco", 2017.

УДК.622.24.05

O.M. Терентьєв, д-р техн. наук, проф. ORCID 0000-0003-2523-2804 M.I. Сергіснко, викладач, ORCID 0000-0001-8284-9072

А.І. Гузан, студент

Національний технічний університет України “Київський політехнічний інститут імені Ігоря Сікорського"

\section{ЗАСТОСУВАННЯ ІННОВАЦІЙНИХ СИСТЕМ ДЛЯ ЕФЕКТИВНОГО БУРІННЯ СВЕРДЛОВИН НА КАР'СРАХ УКРАЇНИ}

Майже по всій Україні в надрах українського кристалічного геологічного щита знаходиться понад 500 млн. м³ розвіданих запасів високоякісного природного будівельного та оздоблювального каменю. Особливу важливість для країни представляють родовища граніту як основної стратегічної сировини для будівництва промислових, оборонних та цивільних споруд, доріг, злітно-посадкових смуг, аеродромів, транспортних тунелів, метро, тощо. Сьогодні в Україні понад 150 кар'єрів видобувають цінну для країни сировину - природний камінь. У той же час, враховуючи високу міцність і абразивність гранітів, їх видобуток надзвичайно складний, дорогий, трудомісткий. Немає машин, які могли б безпосередньо розробляти міцні гранітні породи вулканічного та метаморфічного походження. Для забезпечення необхідних обсягів видобутку і послідуючої переробки граніту, необхідно попередньо подрібнити моноліт гірської породи. Цей складний технічно і технологічний процес здійснюється потужними буровими установками. в міцних і дуже міцних гірських породах бурінням від десятків до сотень свердловин, діаметром від 80 до 350 мм, і глибиної до декількох десятків метрів. Процес завершують заряджанням пробурених свердловин спеціальною вибухівкою, і завершають масовим вибухом.

У представлених дослідженнях проаналізовано та встановлені основні показники, що впливають на ефективність і продуктивність бурових установок на кар'єрах України. Розглянуто, обгрунтовано та рекомендовано раціональні способи руйнування гірських порід для конкретних гірничо-геологічних умов видобувного підприємства. Оптимізація ефективності і продуктивності буріння проводилась шляхом вибору способу руйнування, від міцності гірських порід, типу бурової машини та параметрів породоруйнівних інструментів. Представлена в роботі методика розрахунку дозволяє обмежити пилове забруднення зони бурових робіт в залежності від швидкості і глибини буріння, дозволить вибирати оптимальні режими роботи бурової машини. Отримані результати досліджень підтвердили правильність та ефективність нових інноваційних систем буріння твердих порід на кар'єрах України.

Ключові слова: кар'єр, руйнування гірських порід, бурова установка, пневматичний ударник.

Надійшла 30.06.2020

Received 30.06.2020 